\title{
Change Management in Public High Schools in Jordan, Based on Administrative Innovation principles from the Schools' Principals' Point of View
}

\author{
Hana'a M. Abu Rumman ${ }^{1} \&$ Khaled AlSarhan ${ }^{2}$ \\ ${ }^{1}$ PhD. student, Educational Administration, Jordan University, Amman, Jordan \\ 2 Profess or, Department of Educational Administration and Foundation, University of Jordan, Amman, Jordan \\ Correspondence: Khaled A1Sarhan, Professor, Department of Educational Administration and Foundation, \\ University of Jordan, Amman, Jordan. E-mail: kserhan@ju.edu.jo
}

Received: June 26, 2018

Accepted: July 6, 2018

Online Published: July 28, 2018

doi:10.5539/mas.v12n8p 160

URL: https://doi.org/10.5539/mas.v12n8p 160

\begin{abstract}
The study aimed to identify the actuality of change management within secondary schools in Jordan based on the administrations innovative principles. Where the members of the study consisted of (275) public secondary schools principals of both genders, which were chosen randomly. The descriptive approach has been used since it suits the purpose of study, the study found that the level of administrative innovative principles among public high schools principals were low in its four dimensions (orig inality, fluency, flexibility and sensitivity to problems).

There were statistically significant differences at the level of significance $(0.05)$ in administrative innovation principles related to applying the element of originality with regard to gender, The results showed that there were no statistically significant differences at the level of significance $(0.05)$ in the principles of admin istrative creativity with its four dimensions attributed to scientific qualification, while it showed that there were statistically significant differences at the level of significance $(0.05)$ in the level of sensitivity to the problems attributed to the experience, The researcher recommended the need for change in the management of public secondary schools in Jordan, based on the principles of administrative innovation.
\end{abstract}

Keywords: change management, flexibility, innovative management, originality, fluency, sensitivity to problems

\section{Introduction}

The talk about the importance of developing the leadership role of educational management, in order to bring about the desired changes, a change that is not limited to change this or that administration by changing the administrative units and their organizational structure, but must develop communication patterns, working methods, organizational environment and culture within the institution, by adopting modern management strategies along with their technological dimensions, In terms of systems analysis, informatics, and social dimensions, through the development of human relations, collective leadership, the assertion of democracy, and participation.

High schools in Jordan face many challenges through increasing knowledge, trad itional ad min istrative work and various needs in the light of development and progress. Therefore, it was necessary to change its policy and administrative systems and work methods to keep pace with those challenges, which requires the availability of creative skills of high school leaders since creativity is the mean to achieve development and change in those schools.

Managing change is a preplanned structured and organized efforts to achieve the goals of change, through the proper scientific recruitment of the human, material, technical and technological resources available to the educational institution (Emad Eddin, 2003).

A successful manager is the one who seeks to motivate employees to be productive members, Belong to their work, Developed in their information, Independent in their personalities,

The manager must realize that his administrative strength is derived from the strength of the school staff, and he can't be successful and distinct unless he respect their views, recognized their competencies and shared the 
vision in the development of the school, empower them in decision-making so that the process of decision-making from the bottom of the pyramid of working faculty members to the top of the admin istrative staff, led by the headmaster (Darwaza, 2003).

Many creations and innovations had emerged over the ages, most notably the principles of admin istrative innovation which supported the progress and the development of societies. Since ancient times, societies have developed through the ideas and innovations of thinkers who contributed to the development of societies, during which some of these intellectuals had faced difficulties in introducing their ideas and innovations to the society, since some societies do not accept these new ideas, while insisting on staying in their place, without introducing these ideas and innovations, thinking that such ideas are alien to society and not compatible with their customs and traditions. While there are some who accepted these ideas and contributed to their spread in society. And the question remains; How can these ideas and innovations be mainstreamed into society and how society receive it (Rojers, 2003).

The definitions of creativity have varied and varied, Al-Muhairi (2003) defined it as a flexible scientific imagination aimed to develop an old idea or to find a new one resulting to produce an extraord inary and creative results that can be applied, activated and benefit from. While Guilford (1986) sees it as a set of characteristics that include fluency in thinking, flexibility, originality, sensitivity to problems, redefining the problem and clarifying it in detail.

Admin istrative innovation was expressed by (Jarwan, 2002) as a combination of capacities, preparations and personal characteristics, which require appropriate management to promote mental processes to lead to authentic and useful products characterized by creativity by focusing on the individual's previous experiences, the experiences of the institution and the world community, it can be defined as a process that seeks to make a distinct shift at the organizational level within the institution by generating creative ideas that are genuine, to be implemented by work individuals and its groups, which has a positive impact on the development of the establishment or the organization (Al-Enezi, 2008).

Nasr (2008) defined admin istrative innovation in educational institutions as the ability of school administ ration to acquire creative thinking skills, which can be developed through different methods to develop admin istrative creativity, in order to create new ideas and methods that help to achieve new administrative processes and introduction of development programs for employees, to stimulate the investment of all their abilities and skills, which enables management to achieve the objectives of the institution.

The need for creativity has been and continues to be the cornerstone in all aspects of life and its problems, but the world today, especially educational institutions, which are more in need of creativity than before; Increasing pressures, and many changes that have been exposed, such as globalization and the knowledge economy, made creativity an urgent necessity for all educational institutions (Jarwan, 2008).

Education in its mission aims at raising the potential of mental and creative abilities of the youth in the education process, trying to direct them to be effective and productive to have a positive impact through diversity, innovation and the development of curricula, that allow all students to progress in areas that tend to like as stated by (Al-Anzi, 2008), where attention shifted from focusing on the physical economy to focusing on the knowledge economy, which depends mainly on developing the creative capabilities of human capital, as well as on speed, imagination, flexibility and innovation (Al-zahry, 2002), Which in turn imposed the need for change and renewal on the educational administration, and focus the attention on creative talents and creative innovation, these elements that represent the basis of the thinking in creative management (A1-Baz, 2000).

The role of administrative leaders in managing educational change processes is one of the inputs that can contribute to determining the outcome of change and highlighting its characteristics. The distinction of any educational system can be attributed to the excellence of the administrative process, and to distinguish human inputs, and enable them to carry out their responsibilities efficiently and effectively and because change is an urgent necessity in life, we need to put into effect an effective law because this change does not always go in the positive direction required. Therefore, the change in its nature is a process of conflict between contradictions; between processions of life, and the back pullers and between the new and the old, And between all the elements of transformation in this life. While change is the result of intentional action, leading to the fact that change is a process, and not an incident, therefore, as a process, it needs the effort, time and programs to create it.

In light of rapid and successive changes in all aspects of life with the emergence of new trends, creative innovations, science and knowledge and New inventions, school principal must adapt to the global, regional and local environment in which he or she is located, through studying the conditions and circumstances surrounding it and anticipating future changes, and looking ahead, through the work of researchers as a university doctor and 
a school director, and their observation of high school principals and their relationship to them, change management is of strong importance in our schools and the importance of administrative innovation in the educational work in Jordan, which requires the presence of the creative leader who is able to transform his traditional management into a change management that is compatible with the demands of times.

Therefore, the researchers chose this topic because of its importance in finding a creative leader who can face the challenges imposed on him in this age and raise his school forward.

\subsection{Study Problem}

The problem of the study is to identify the requirements of change management in public secondary schools in Jordan based on the administrative innovation principles.

\subsection{Objective and Questions of the Study}

The study aims to identify change management within secondary schools in Jordan based on the principles of administrative innovation by answering the following questions:

1- What is the reality of change management within the public secondary schools in Jordan based on the principles of administrative innovation from the point of view of its principals?

2 - Are there differences with the change at the level of significance $(\alpha=0.05)$ for the reality of change management based on the principles of administrative creativity from the point of view of secondary school principals in Jordan attributed to (gender, academic qualification, years of experience)?

\subsection{The Importance of the Study}

The importance of the theoretical study stems from:

- Provide the local community at all levels with results that reveal the extent of activating the principles of administrative innovation in secondary schools in Jordan and their effectiveness in managing the changes.

- To provide a systematic perspective, which can be used by educational leaders in schools to understand the processes of change in their organizations, which may contribute to reducing the obstacles of change and obstacles to the improvement of organizational effectiveness in different fields of work based on the principles of administrative innovation.

The importance of applied study stems from:

- Highlighting the management of change, which started to catch attention since the end of the twentieth century, and all educational systems without exception have begun to assimilate, in order to reform their inputs and processes.

\subsection{Terminology of Study}

The study adopts the following terms:

\subsubsection{Change Management}

Defined by Emad Eddin (2003) as "managing the planned and organized effort to reach the desired goals of change through the proper scientific recruitment of the human, material, technical and technical resources available to the educational institution."

The researchers defined the process of change management as a process in which a comprehensive plan is designed to bring about changes in the current situation by investing all available resources in the educational institution and in the surrounding environment through developing the vision and the joint mission of the school, Supporting the change and presenting the behavioral model and the intellectual stimulation of the workers until we reach the desired change, and this could be measured by the overall degree obtained by the principals by responding to the paragraphs of the questionnaire.

\subsubsection{Administrative Creativity}

Defined by Al-Qahtani (2001) as: "the Use of employee personal creative skills, in devising new management methods that lead to innovative solutions to a new administrative problem or new perceptions to address this problem based on objective analys is and structured creative effort related to sensory perception based on analysis, testing, experimentation and evaluation".

The researchers identified the procedural administrative innovation as a: the ability of the school principals to find new ways and methods that stem from thinking and creative abilities of orig inality, fluency, flexibility, sensitivity to problems, risk, challenge and retention of direction, analys is and linkage in order to improve the 
administrative level and keep pace with change, measured by the degree to which principals get from the questionnaire.

\subsection{Study Limits}

The results of the study can be generalized in light of the following limits:

- Human Boundaries: This study was limited to the principals of public secondary schools in Jordan.

- Temporal and spatial limits: The results of this study were determined on secondary government schools in Jordan in the second semester of 2017/2018.

\section{Previous Studies}

\subsection{Arabic Studies}

The aim of the study of Habil (2008) to see how high school principals in Gaza Governorate practice their ro le as leaders of change from the point of view of their teachers, the impact of:

Gender, educational area and years of experience) from the point of view of teachers in their practice of managing change, the researcher used the descriptive analytical approach, the study population reached (3234) teachers and teachers, the sample was selected in the random stratified form (328) teachers. The questionnaire was used as a tool to measure the reality of change, the results showed that the degree of principals practicing of change management was $74.6 \%$. The study recommended the adopting of change administration in secondary schools by the Ministry of Education.

While the study of Al-Subaie (2009) aimed at determining the importance of the leadership roles of the principals of education, in light of change management requirements, Degree and feasibility of its use, and the most important obstacles that prevent it, from the point of view of members of the study community, the researcher used the descriptive analytical approach, the study population consisted of all the principals of education and their assistants in the departments of education for boys in the Kingdom of Saudi Arabia which reached (100) persons, and the sample was applied on them. The questionnaire was used as a tool for collecting information, the data were processed using the SPSS statistical program, and the most prominent results of the study were; that the leadership roles of education principals in the light of the requirements of change management is very important from the point of view of members of the study community, and that there are obstacles that prevent the principals of education to exercise their leadership roles in the light of the requirements of change management.

Study of the Al-Ajez and Shuldan (2010), aimed to identify the role of school leadersh ip in developing creativity among secondary school teachers in the Gaza Strip governorates from the point of view of teachers. The two researchers used the analytical descriptive approach to this type of study, The study sample consisted of (303) persons representing (11\%) of the orig inal population (3416), the study reached a number of recommendations, including the selection of well-prepared school leaders, who believes in the importance of creativity in the school environment, and seeks to develop it among teachers and learners as well.

\subsection{Foreign Studies}

The study of Zara and Zadeh (2013) which aimed at understanding the relationship between school administration and the creativity of principals and teachers of public schools in the city of Mahmoudabad in Iran, by using the descriptive approach, the sample consisted of (40) principals and (100) teachers, the results of the study found that the administrative innovation in schools is reflected positively on the performance of principals, teachers and students, the study stressed the necessity to pay extra attention to establish of administrative innovation training programs in secondary schools, due to its positive results on schools educational performance, the study recommended the development of creative thinking for school principals through the use of guidance exercises to increase their problem solving abilities, self-control and attention to issues that lead to the development of Creative systematic thought of the schools principals.

Nwangwa \& Omotere (2013) conducted a study aimed at identify ing the new roles of high school principals and identifying the impact of change management. The experimental method was used, and the study sample consisted of four randomly selected schools. The results of the study showed that the impact of the implementation of change management in secondary schools has been positive for the development and advancement of the teaching and learning process through the implementation of performance-based manage ment. The results of the study showed that at first there were difficulties in apply ing change management to the teaching and administrative staff and that required understanding of the new roles of the principals in managing the change. 
The Ibrahim and Don (2014) study sought to identify the impact of effective management on the implementation of change management in Malaysian schools. The standard approach was used. The study sample consisted of (342) teachers and principals in secondary schools in the northern region of Malaysia. The results of the study showed that the effective management contributed positively to the implementation of change management in secondary schools. The study showed that change management contributes to the improvement of school performance in general in terms of teachers and students. The results of the study showed also that secondary schools in Malaysia still suffer challenges and difficulties faced by administrators when applying change management. The study recommended that the policy of the State of Malaysia should adopt the change management approach in secondary schools.

\subsection{Current Study Site from Previous Studies}

By reviewing the previous studies related to the current study, and to identify their theoretical literature and methodology, the two researchers found the following: the studies that dealt with the management of change was important, but these studies did not link the management of change with the ad ministrative innovation princip les. In addition the methodological approach in these studies which varied between descriptive based on actual situation and Reality and analytical in addition to the developmental approach.

The researchers noted that there is a series of studies dealing with administrative innovation as synonymous with successful management, as in the study of Al-Ajez and Shaldan (2010). Beside that most studies also recommended that school principals should be pay more attention to creativity and disseminate it among teachers and all staffs in the school, because of its clear impact on the success of the educational institution. The two researchers benefited from previous studies in the preparation of the theoretical framework and enriching it with many ideas related to the creative headmaster and administrative creativity which were the basics that helped them in constructing the study questionnaire.

\subsection{This Study is Distinguished from Previous Studies with the Following}

This study is distinguished from the previous studies that it dealt with the topic of

Developing the requirements of change manage ment based on the principles of adminis trative innovation among high school principals in Jordan from the point of view of principals, it was applied in Jordan which was not addressed in any other studies, where most of the previous studies were applied in different societies between Arab and foreign countries.

This study focused on the development of change management requirements based on the administrative innovation principles and this was not dealt with in previous studies.

\section{Method and Procedures}

\subsection{Study Approach}

This study is based on the use of the descriptive approach, in order to suit the current study objectives related to "managing change in public secondary schools in Jordan based on principles of ad min istrative innovation" from the principals point of view.

\subsection{Society and Study Sample}

The study population consists of all (1296) principals of the public secondary schools in Jordan, of whom (567) are males and (729) are females, according to the Ministry of Education statistics for the academic year. The study sample was chosen by random class method from the Secondary schools in the North, Central and Southern Provinces in Jordan totaling (275) schools.

\subsection{Study Tool}

The study tool was developed to measure change management in public secondary schools in Jordan based on the principles of administrative innovation, from the point of view of schools principals (principles), with reference to theoretical literature and previous studies such as (Al-Ajez \& Shaldan, 2010), and (Ozmen and Muratoglu, 2010).

\subsection{Study Tool Validity}

The study was validated using the method of verifying the content. The scale was presented to the faculty members in the Department of Educational Administration at the University of Jordan, Yarmouk University and Mu'tah university to express their opinions on the validity of the content and the relevance of the phrases to the scale and its suitability to measure what was set for measurement, and then the appropriate amendments were proposed, and a criterion $(80 \%)$ was adopted to indicate the validity of the paragraph. 


\subsection{Study Instrument Stability}

To verify the stability of the study instrument, the researcher identified the consistency of each paragraph of the scale with the dimension to which the paragraph belongs, using the Cronbach-Alpha- coefficient. Table (1) shows the results of the test.

\subsection{Study Variables}

The study included independent variables that include the administrative creativity principles, namely (orig inality, fluency, flexibility, sensitivity to problems), intermediate variables which include (gender, scientific qualification and experience), in addition to the dependent variable that includes change management in public secondary schools.

Table 1. Stability coefficients for study tool paragraphs using the Kronbach Alpha test

\begin{tabular}{lc}
\hline Study variables & Study Variables Stability Factor Using Alpha Cronbach \\
\hline Authenticity & 0.87 \\
Fluency & 0.76 \\
Flexibility & 0.83 \\
Sensitivity to problems & 0.81 \\
\hline
\end{tabular}

Table (1) shows that the values of the Cronbach alpha coefficient for the sub-dimensions of the scale ranged from 0.76 to 0.87 .

\section{Study Results}

\subsection{Results Related to the First Question}

What is the reality of change management within the public secondary schools in Jordan based on the of administrative innovation principles from the point of view of its principals?

To answer the question, Mean and Standard Deviations (SD) were extracted to identify the responses of the study sample members on change management reality within public secondary schools in Jordan based on the principles of administrative innovation from the point of view of their principals as shown on table (2).

Table 2. Mean and the Standard Deviations (SD) of the responses of study sample members on "The reality of change management within public secondary schools in Jordan based on the principles of administrative creativity" arranged in descending order

\begin{tabular}{llllll}
\hline No. & The principles of administrative creativity & Mean & SD & order & level \\
1 & originality & 2.00 & 0.32 & 1 & low \\
2 & fluency & 1.89 & 0.29 & 2 & low \\
4 & flexibility & 1.88 & 0.33 & 3 & low \\
5 & sensitivity to problems & 1.86 & 0.34 & 4 & low \\
& Total score of the scale & 1.91 & 0.19 & & low \\
\hline
\end{tabular}

Table (2) shows that Mean of (The reality of managing change within public secondary schools in Jordan based on administrative innovation princip les), ranged between (2.00 and 1.86), where the element of orig inality came first, in the last place was the sensitivity component of the problems, All dimensions were within the low level, This finding may be due to the fact that principals do not accept good scientific approach and new ideas on educational issues, and resist change management.

Below is the level of sub-paragraphs for each dimension of administrative innovation principles applied in public secondary schools, which reflect change management in schools.

\section{1- Originality Element Applied Degree}

Mean and standard deviations had been extracted from responses of the sample members for the degree of applying the originality component in the public secondary schools. Table (3) shows that: 
Table 3. Mean and standard deviations of the responses of the study sample members on paragraphs the degree of application of the originality element is arranged in descending order

\begin{tabular}{llllll}
\hline No. & Paragraph & Mean & SD & Order & level \\
\hline 4 & Respect new views on educational issues & 2.20 & 0.94 & 1 & Low \\
3 & Apply IT for administrative work & 2.08 & 0.92 & 2 & Low \\
5 & Uses appropriate methods to achieve educational policy objectives & 2.04 & 0.93 & 3 & Low \\
6 & Developing self-censorship among teachers. & 1.98 & 0.85 & 4 & Low \\
1 & Accomplish his work in a sophisticated manner & 1.94 & 0.75 & 5 & Low \\
7 & Provides alternatives to new solutions to educational issues. & 1.93 & 0.85 & 6 & Low \\
2 & Apply New methods in the schoolto solve any problem & 1.80 & 0.68 & 7 & Low \\
& average Mean & 2.00 & 0.32 & & Low \\
\hline
\end{tabular}

Table (3) shows that the degree of (originality element applaied) in the public secondary schools in Jordan from the perspective of its managers is low, Paragraph (4) has the highest mean of 2.20, by standard deviation (0.94), a low level, the paragraph states that the Director (respects new views on educational issues). In the last position, paragraph (2) came with an average of (1.80) and a standard deviation (0.68), where the paragraph states that the Director (applies new methods in the school to solve any problem), this result may be attributed to a lack of respect for new views on educational issues, weak employment of information technology for administrative work and not providing solutions to educational issues.

\section{2- Fluency element Applied degree:}

The statistical averages and the standard deviations of the responses of the sample members of the sample were extracted from the applied fluency component in the government secondary schools. Table (4) shows that:

Table 4. Mean and Standard Deviations (SD) of study sample members responses for paragraphs of "fluency element applied" ranked in descending order

\begin{tabular}{|c|c|c|c|c|c|}
\hline No. & paragraph & Mean & SD & Order & Level \\
\hline 2 & Seeks to overcome the obstacles to achieving the goals. & 2.05 & 0.89 & 1 & low \\
\hline 1 & Has communication skills & 1.93 & 0.78 & 2 & low \\
\hline 6 & Brainstorming is used as a means of stimulating thought among teachers. & 1.91 & 0.88 & 3 & low \\
\hline 3 & $\begin{array}{l}\text { Encourage teachers to discuss and dialogue to find solutions to } \\
\text { educational problems. }\end{array}$ & 1.89 & 0.81 & 4 & low \\
\hline 5 & Ask open-ended questions about the problems. & 1.85 & 0.76 & 5 & low \\
\hline 4 & He is keen to convince teachers of his views on educational subjects & 1.81 & 0.74 & 6 & low \\
\hline 7 & $\begin{array}{l}\text { He is keen to express the views of the teachers even if he violates his } \\
\text { opinion }\end{array}$ & 1.77 & 0.73 & 7 & low \\
\hline & mean & 1.89 & 0.29 & & low \\
\hline
\end{tabular}

Table (4) shows that (fluency component applied degree) in Jordan public secondary schools from the perspective of its managers low level, Paragraph (2) has the highest mean (2.05), and with a standard deviation (0.89), which also show low level, the paragraph stated that the Director (seeks to overcome the obstacles to achieve the objectives). In the last rank, paragraph (7) came with an average of (1.77) and with a standard deviation (0.73) which is considered low, where the paragraph states that the director (keen to exp ress the views of teachers even if it violated his opinion). This result may be attributed to that managers do not seek to overcome the obstacles to achieve the goals they planned, and that they do not have adequate communication skills, and that they do not use brainstorming as a mean to stimu late thinking among teachers, this weakens and limits their fluency required to manage change based on the weakness of creative principles in the ad min is trative side.

\section{3- Flexibility Applied Degree:}

Upon calculating Mean and Standard Deviations (SD) of the study sample members' responses were ext racted from the paragraphs of flexibility component applied in the public secondary schools. Table 5 illustrates: 
Table 5. Mean and Standard Deviations (SD) of the study sample members' responses for paragraphs "Flexibility applied Degree" ranked in descending order

\begin{tabular}{|c|c|c|c|c|c|}
\hline No. & Paragraph & mean & SD & order & level \\
\hline 6 & Responds to new situations often. & 2.18 & 1.00 & 1 & low \\
\hline 5 & $\begin{array}{l}\text { Prioritize the implementation of training programs for teachers according } \\
\text { to the available resources. }\end{array}$ & 2.00 & 0.95 & 2 & low \\
\hline 7 & Adjusts his position when he is convinced that he is not correct. & 1.95 & 0.73 & 3 & low \\
\hline 4 & Assign tasks to teachers according to their specialties & 1.93 & 0.93 & 4 & low \\
\hline 3 & Uses a variety of dialogue methods when pres ented to educational topics. & 1.76 & 0.76 & 5 & low \\
\hline 2 & View educational issues from multiple angles. & 1.75 & 0.73 & 6 & low \\
\hline \multirow[t]{2}{*}{1} & Seeking ideas that contribute to solving work problems & 1.59 & 0.61 & 7 & low \\
\hline & Mean & 1.88 & $\mathbf{0 . 3 3}$ & & low \\
\hline
\end{tabular}

Table (5) shows that (Flexibility component applied degree) within the public secondary schools in Jordan from the principals perspective is considered low. Paragraph (6) received the highest mean at 2.18, and with a standard deviation (1.00), which is also low level, the paragraph stated that the Director (often responding to new situations) came in last position, paragraph (1) came with Mean (1.59) and with a standard deviation (0.61), the paragraph states that the director (seeking ideas that contribute to solving work problems), this result may be attributed to the general decline in response to new positions often by managers, and not prioritize the implementation of training programs for teachers in accordance with the available capabilities as required.

\section{4- The degree of applying sensitivity component to the problems:}

The Mean and standard deviations of individuals study responses were extracted from the paragraphs for the component of sensitivity applied degree to the problems in public secondary schools, as illustrated on table (6):

Table 6. standard deviation and means for the responses of study sample members on the paragraphs, the degree of applied sensitivity component to problems "is arranged in descending order.

\begin{tabular}{llllll}
\hline No. & Paragraph & Mean & SD & Order & level \\
\hline 1 & Has a precise vision of the work problems in the educational institution & 2.06 & 0.96 & 1 & low \\
2 & Organize problems according to priorities & 1.94 & 0.86 & 2 & low \\
7 & Searching for creative alternatives to problem solving. & 1.91 & 0.82 & 3 & low \\
3 & patiently deals with the problems he faces & 1.85 & 0.85 & 4 & low \\
5 & Uses scientific thinking methodology to solve problems. & 1.84 & 0.71 & 5 & low \\
6 & Committed to objectivity when dealing with educational problems. & 1.84 & 0.71 & 6 & low \\
4 & Encourages team spirit to solve problems. & 1.55 & 0.60 & 7 & low \\
\hline & Average Mean & 1.86 & 0.34 & & low \\
\hline
\end{tabular}

Table (6) shows that (the degree of sensitivity component applied to problems) in the public secondary schools in Jordan from the perspective of its managers is considered of low level. Paragraph (1) has the highest mean of (2.06) with standard deviation of (0.96) scoring low level, The paragraph stated that the director (has a precise vision of work problems in the educational institution. While paragraph (4) scored last with mean (1.55) and (0.60) of standard deviation, which is still considered low, the paragraph stated that the headmaster encourages team spirit in problem solving. This result may be attributed to the general weakness in having a precise vision of the work problems in educational institutions, while problem solving is not prioritized according to their importance, in addition to the general weakness in the innovative solutions search by managers to solve the problems as they occur.

\subsection{Results Related to the Second Question}

Are there significant differences at the level of $(\alpha=0.05)$ according to the reality of change management according to the princip les of administrative innovation from the point of view of secondary school principals in Jordan attributed to (gender, academic qualification, years of experience)?

To identify the differences in the reality of change management based on the principles of administrative innovation from the point of view of secondary school principals in Jordan, which are attributed to gender and scientific qualification, years of experience variables; having applied the Independent Sample T-test, One Way ANOVA test and Schiffe test; leading to the following results: 


\subsubsection{First: Gender}

Independent Sample T-test was used to identify the differences in the reality of change management based on the principles of managerial innovation fro $m$ the point of view of secondary school principals in Jordan attributed to gender, table 7 illustrates this:

Table 7. Independent Sample T-test to identify differences in the reality of change management based on the principles of administrative innovation from the point of view of secondary school principals in Jordan, attributed to gender variable

\begin{tabular}{|c|c|c|c|c|c|c|}
\hline Source & Gender & $\mathbf{N}$ & Mean & $\begin{array}{l}\text { Standard } \\
\text { deviation }\end{array}$ & $\mathbf{T}$ & Sig. \\
\hline \multirow[t]{2}{*}{ originality element applied } & Male & 143 & 2.03 & 0.31 & \multirow{2}{*}{2.086} & \multirow{2}{*}{0.038} \\
\hline & Female & 132 & 1.95 & 0.32 & & \\
\hline \multirow{2}{*}{ fluency element applied } & Male & 143 & 1.89 & 0.30 & \multirow{2}{*}{0.131} & \multirow{2}{*}{0.896} \\
\hline & Female & 132 & 1.89 & 0.29 & & \\
\hline \multirow[t]{2}{*}{ Flexibility element applied } & Male & 143 & 1.89 & 0.33 & \multirow{2}{*}{0.261} & \multirow{2}{*}{0.794} \\
\hline & Female & 132 & 1.88 & 0.34 & & \\
\hline \multirow{2}{*}{$\begin{array}{l}\text { Apply an element of sensitivity arising } \\
\text { from problems }\end{array}$} & Male & 143 & 1.80 & 0.34 & \multirow{2}{*}{3.142} & \multirow{2}{*}{0.002} \\
\hline & Female & 132 & 1.92 & 0.33 & & \\
\hline \multirow[t]{2}{*}{ Total } & Male & 143 & 1.90 & 0.19 & \multirow{2}{*}{0.446} & \multirow{2}{*}{0.656} \\
\hline & Female & 132 & 1.91 & 0.19 & & \\
\hline
\end{tabular}

* Statistically functional at the level of significance $(0.05)$ and less.

The results shown in Table (7) that there were statistically significant differences at significance level (0.05), in the reality of managing change based on the principles of ad min is trative creativity on the dimensions; (Applying of originality element and of sensitivity element to problems), from the point of view of secondary school principals in Jordan due to gender. The statistical value of (t) $(2.086,3.142)$, which are values at the level of significance (0.05) and less, found that the source of differences in applying the element of orig inality in favor of males. This indicates that male principals apply the element of originality through the use of appropriate methods to achieve the objectives of education policy, and to develop the method of self-censorship of teachers in addition to the completion of the work entrusted to them in a sophisticated manner is higher than females principals, which reflects that female principals need to bring about change management based on the element of originality rather than male managers. The results of the study showed that the source of differences in the application of the sensitivity component of the problems in favor of female managers with an increase in the arith metic average of the male arith metic mean, but the overall level was low for females and males, with regard to applying the sensitivity component to problems. This result may be attributed to the fact that female directors are in state secondary schools have a precise vision of the problems of work in educational institutions, The problems are determined by their importance in priority and higher than male managers, because of their high level of sensitivity and are inherently emotional seeking to reduce the problems within the educational institution, which leads to the need to bring change management to male managers more than female directors in this aspect.

\subsubsection{Academic Qualification}

One Way ANOVA was used to identify the differences in the reality of change management based on the principles of managerial innovation fro $m$ the point of $v$ iew of secondary government secondary school principals in Jordan, attributed to the variable of scientific qualification. Table (8) illustrates this:

Table 8. One Way ANOVA Test to learn about the reality of change management Based on the principles of administrative innovation from the point of view of secondary school principals in Jordan, attributed to the variable of scientific qualification.

\begin{tabular}{lllllll}
\hline source & & $\begin{array}{l}\text { Sum } \\
\text { squares }\end{array}$ & of & Mean Squares F & Sig. \\
\hline Originality & Between groups & 0.005 & 2.000 & 0.003 & 0.026 & 0.974 \\
\cline { 2 - 7 } & Within groups & 27.582 & 272.000 & 0.101 & & \\
\hline
\end{tabular}




\begin{tabular}{|c|c|c|c|c|c|c|}
\hline & Total & 27.587 & 274.000 & & & \\
\hline \multirow[t]{3}{*}{ Fluency } & Between groups & 0.040 & 2.000 & 0.020 & 0.226 & 0.798 \\
\hline & Within groups & 23.798 & 272.000 & 0.087 & & \\
\hline & Total & 23.837 & 274.000 & & & \\
\hline \multirow[t]{3}{*}{ Flexibility } & Between groups & 0.025 & 2.000 & 0.012 & 0.109 & 0.897 \\
\hline & Within groups & 30.716 & 272.000 & 0.113 & & \\
\hline & Total & 30.741 & 274.000 & & & \\
\hline \multirow[t]{3}{*}{$\overline{\text { Sensitivity }}$} & Between groups & 0.580 & 2.000 & 0.290 & 2.576 & 0.078 \\
\hline & Within groups & 30.624 & 272.000 & 0.113 & & \\
\hline & Total & 31.204 & 274.000 & & & \\
\hline \multirow[t]{3}{*}{ Total } & Between groups & 0.014 & 2.000 & 0.007 & 0.197 & 0.821 \\
\hline & Within groups & 9.692 & 272.000 & 0.036 & & \\
\hline & Total & 9.707 & 274.000 & & & \\
\hline
\end{tabular}

Table (8) shows that there are no statistically significant differences in the reality of change management based on the principles of administrative innovation fro $m$ the point of $v$ iew of government secondary school principals in Jordan due to the variable of scientific qualification. $(0.109,2.576,0.197)$ respectively, wh ich are statistically insignificant at the significance level (0.05), and the differences between mean, if any, did not reach the level of statistical significance, and this indicates the consensus in the views of secondary school principals to bring about change based on the applying of creativity principles, which suffers from general weakness, regardless of the scientific qualification of the principals.

\subsubsection{Experience}

The One Way ANOVA test, in addition to Scheffe Test, were used to identify differences in the reality of change management based on the principles of managerial innovation from the point of view of secondary government principals in Jordan, attributed to the experience variable. Table 9 illustrates this:

Table 9. One Way ANOVA Test to learn about the reality of change management Based on the principles of administrative innovation from the point of view of secondary school principals in Jordan, attributed to the variable of experience

\begin{tabular}{lllllll}
\hline source & & $\begin{array}{l}\text { Sum of } \\
\text { Squares }\end{array}$ & Df & $\begin{array}{l}\text { Mean } \\
\text { Squares }\end{array}$ & F & Sig. \\
\hline \multirow{3}{*}{ Originality } & Between groups & 0.024 & 2 & 0.012 & 0.120 & 0.887 \\
& Within groups & 27.563 & 272 & 0.101 & & \\
& Total & 27.587 & 274 & & & \\
Fluency & Between groups & 0.266 & 2 & 0.133 & 1.533 & 0.218 \\
& Within groups & 23.571 & 272 & 0.087 & & \\
& Total & 23.837 & 274 & & & \\
\multirow{5}{*}{ Flexibility } & Between groups & 0.650 & 2 & 0.325 & 2.940 & 0.055 \\
& Within groups & 30.090 & 272 & 0.111 & & \\
& Total & 30.741 & 274 & & & \\
Sensitivity & Between groups & 0.890 & 2 & 0.445 & 3.992 & 0.020 \\
& Within groups & 30.314 & 272 & 0.111 & & \\
& Total & 31.204 & 274 & & & \\
\multirow{2}{*}{ Total } & Between groups & 0.258 & 2 & 0.129 & 3.709 & 0.026 \\
& Within groups & 9.449 & 272 & 0.035 & & \\
& Total & 9.707 & 274 & & &
\end{tabular}

The results shown in Table (9) that there were statistically significant differences at (0.05) in the reality of change management based on the principles of administrative creativity related to dimension (sensitivity to problems and total measurement), from the point of view of secondary school principals in Jordan, due to the variable experience, where the $(\mathrm{F})(3.992,3.709,6.102)$ respectfully, which are values at the level of sign ificance $(0.05)$ and less, to identify the source of the differences, Scheffe test was used for post-comparisons, were the results are shown in Table (10) below. 
The results showed no statistically significant differences at the significance level $(0.05)$ in the reality of change management, based on the principles of admin istrative creativity related to dimensions (originality, fluency) from the point of view of secondary school principals in Jordan, attributed to the variable experience, with a statistical value of $(\mathrm{F})(0.120,1.533,2.940)$ respectively, these values are not significant at the level of significance $(0.05)$ or less.

Table 10. The Schiffe test for post-comparisons to identify the source of differences in the level of sensitivity to problems and overall measurement due to the variable of experience

\begin{tabular}{|c|c|c|c|c|}
\hline $\begin{array}{l}\text { Dependent } \\
\text { variables } \\
\end{array}$ & (I) experience & $\begin{array}{l}\text { (J) experience } \\
\text { Years }\end{array}$ & $\begin{array}{lr}\text { Mean } & \text { di } \\
\text { between } & (\mathrm{I}-\mathrm{J}) \\
\end{array}$ & $\begin{array}{l}\text { Statistical } \\
\text { significance }\end{array}$ \\
\hline \multirow{12}{*}{ Total } & \multirow{4}{*}{$6-10$ years } & $6-10$ & $*_{-0.11795}$ & 0.039 \\
\hline & & 10 or more & -0.13445 & 0.077 \\
\hline & & Less than 6 & $.117950 *$ & 0.039 \\
\hline & & 10 or more & -0.01650 & 0.955 \\
\hline & \multirow[t]{2}{*}{10 years or more } & Less than 6 & 0.13445 & 0.077 \\
\hline & & $6-10$ & 0.01650 & 0.955 \\
\hline & \multirow[t]{2}{*}{ Less than 6 years } & $6-10$ & -0.03369 & 0.424 \\
\hline & & 10 or more & $-* 0.08992$ & 0.026 \\
\hline & \multirow[t]{2}{*}{ 6-10 years } & Less than 6 & 0.03369 & 0.424 \\
\hline & & 10 or more & -0.05622 & 0.185 \\
\hline & \multirow[t]{2}{*}{10 years or more } & Less than 6 & $0.08992 *$ & 0.026 \\
\hline & & $6-10$ & 0.05622 & 0.185 \\
\hline
\end{tabular}

* Statistically functional at the level of significance (0.05) and less.

The results of the Schiffe test for post-comparisons show that the source of differences in the level of sensitivity to problems as one of the dimensions of the principles of admin istrative innovation, it was for the category of managers with experience (6-10) years the source of the differences in the level of principles of admin istrative innovation on the overall measurement of principals in government high schools for the benefit of the experienced category (10) years and more.

This result may be attributed to the higher the level of experience of managers the more the level of administrative innovation is increased, calculating the values of the mean, the overall level of managerial innovation was generally low, which calls for change.

\section{Recommendations}

In light of the results of the study, the researcher recommended the following:

- The need for government high schools to manage change to raise the level of administrative creativity among schoolprincipals.

- Work on subjecting the directors of public schools to training courses that increase the level of their administrative creativity related to originality, flexibility, fluency and sensitivity to problems.

- Participating in seminars, conferences and workshops that are concerned with administrative creativity among managers.

- Dissemination of the results of this study to public schools to follow up the level of managerial creativity among principals, and work on the development of future plans to bring about change.

\section{References}

Alajez, F., Ali, S., \& Faiz, K. (2010). The role of school leadership in the development of creativity among teachers of secondary schools in the Gaza Strip from teachers point of view. Journal of the Islamic University, Series of Humanitarian Studies, $18(1), 37$.

Albaz, A. (2000). Management of Innovation in Educated Organizations, Unpublished Master Thesis, Yarmouk University, Irbid, Jordan.

Alhabil, A. I. (2008). The reality of change management among secondary school principals in Gaza Governorate from the point of view of their teachers, unpublished master thesis, Gaza, Islamic University. 
Al-Muhairi, A. (2003). Creativity Your Way towards Future Leadership, Cairo: Dar Al Ma'aref.

Al-Qahtani, S. (2001). Administrative Leadership - Transition to Global Leadership Model, Riyadh: Marmar Printing Press.

Al-Subaie, O. B. A. (2009). Leadership roles for education principals in light of change management requirements. Unpublished doctoral dissertation, Umm Al Qura University, Makkah, Saudi Arabia.

Alzahry, R. (2002). Admin istrative Creativity in the Shadow of Bureaucracy. The World of Thought Magazine, Kuwait, 30(3).

Anzi, A. (2008). The level of administrative creativity among school principals in the north of Saudi A rabia from the perspective of teachers and educational supervisors, Unpublished Master Thesis, Yarmouk University, Irbid, Jordan.

Darwaza, A. N. (2003). The ability of the school headmaster to make developmental decisions and make changes, Journal of the Union of Arab Universities. (41).

Emad, E., \& Mona, M. (2003). Evaluation of the Effectiveness of the School Management Development Program in Preparing the Director of the School in Jordan for Leadership in Change, Unpublished Doctoral Dissertation, Amman: Academic Book Center.

Guilford, J. P. (1986), Creative talents: Their Nature, Uses and Development. New York: barely Limited.

Ibrahim, I., \& Don, Y. (2014). Servant Leadership and Effective Changes Management in Schools, International Journal of Scientific and Research Publications.

Jarwan, F. A. R. (2008). Talent, Excellence and Creativity, Amman: Dar Al Fikr for Printing, Publishing and Distribution.

Nasr, A. J. (2008). Administrative Innovation and SelfDevelopment of the General Secondary School - Strategic Vision, National Center for Educational Research.

Nwanging, K., \& Omotere, T., (2013). The new roles of school managers in managing educational changes in Nigerian school. European Scientific Journal, 9(25), 1857-7881.

Rogers, E. M. (2003). Diffusion of innovations.(th edition) New York, NY: Free Press .

Zara, M., \& Zade, R., (2013). Investigation of relationship between school based management and creativity of principals and teachers in public schools for boys at Mahmoud Abad city. Advances in Environmental Biology Journal, 7(13), 69-43.

\section{Copyrights}

Copyright for this article is retained by the author(s), with first publication rights granted to the journal.

This is an open-access article distributed under the terms and conditions of the Creative Commons Attribution license (http://creativecommons.org/licenses/by/4.0/). 